\title{
PTEN/MMACI expression in melanoma resection specimens
}

\author{
M Deichmann*,', M Thome', A Benner', U Egner', W Hartschuh' and H Näher' \\ 'Department of Dermatology, University Clinics of Heidelberg, Vossstraße 2, 69115 Heidelberg, Germany; ${ }^{2}$ Central Unit Biostatistics, German Cancer Research \\ Center R0700, Im Neuenheimer Feld 280, 69120 Heidelberg, Germany
}

\begin{abstract}
PTEN/MMACI, a tumour suppressor gene located on chromosome 10q23.3, has been found to be deleted in several types of human malignancies. As the chromosomal region 10q22-qter commonly is affected by losses in melanomas, we addressed this gene as tumour suppressor candidate in melanomas. Investigating PTEN/MMACl expression at mRNA level by semiquantitative reverse transcription-polymerase chain reaction, we did not find a statistically significant down-regulation in melanoma resection specimens in comparison to acquired melanocytic nevi from which melanomas quite often are known to arise. Upon immunohistochemistry, PTEN/MMACl protein expression in melanomas was not lost. Sequencing the PTEN/ $\mathrm{MMACl}$ cDNAs in 26 melanoma resection specimens (2I primary melanomas, five metastases), we detected three point mutations and two nucleotide deletions which did not represent genetic polymorphisms. With respect to the predicted protein sequences, all three point mutations were silent whereas the two frame shifts at the extreme C-terminus resulted in a loss of the putative PDZ-targeting consensus sequence. As loss of this motif possibly impairs localization and function of PTEN/MMACI in the two corresponding primary tumours, alterations of this tumour suppressor protein may participate in some melanomas.

British Journal of Cancer (2002) 87, I431-1436. doi: I0.1038/sj.bjc.6600653 www.bjcancer.com

(c) 2002 Cancer Research UK
\end{abstract}

Keywords: melanoma; PTEN/MMACI; tumour suppressor gene

Melanomas are one of the most aggressive of the skin cancers and have shown a dramatic increase in incidence over the past decades (Rigel et al, 1996). The genetic principles that underly the development and progression of these tumours are only beginning to emerge. Genomic regions that exhibit losses of heterozygosity $(\mathrm{LOH})$ and therefore suggest the presence of tumour suppressor genes in sporadic melanomas, have been identified, among others, at chromosomes 6q22-27 (Albino et al, 1994) and 11q22-23 (Robertson et al, 1999). Moreover, LOHs at chromosome 10 occur in $30-60 \%$ of both early- and advanced-stage tumours (Newton, 1994; Bastian et al, 1998) and are an indicator of a poor clinical prognosis (Healy et al, 1998). Segmental deletions were cytogenetically localized to 10q (Richmond et al, 1986; Parmiter et al, 1988; Isshiki et al, 1993; Indsto et al, 1998) and subsequently narrowed by studies of LOH to 10q22-qter (Isshiki et al, 1993; Herbst et al, 1994; Walker et al, 1995; Healy et al, 1996). This region is also a common target of $\mathrm{LOH}$ in a wide spectrum of sporadic cancers, including neoplasias of the prostate (Trybus et al, 1996), thyroid (Nelen et al, 1996), kidney (Speicher et al, 1994), endometrium (Nagase et al, 1996), and bone (Raskind et al, 1996). Investigating kinetics of melanoma tumour formation in animals, transfer of chromosome $10 \mathrm{q}$ distal to $10 \mathrm{q} 23.1$ into melanoma cells caused a severe reduction in tumour growth (Robertson et al, 1999).

One notable gene at the chromosomal locus 10q23.3 is the tumour suppressor gene 'phosphate and tensin hommolog deleted on chromosome ten' (PTEN; Li et al, 1997; Steck et al, 1997), also known as 'mutated in multiple advanced cancers' (MMAC1). By dephosphorylating the phosphatidylinositol-3,4,5-triphosphate, this

*Correspondence: Dr M Deichmann;

E-mail: martin_deichmann@med.uni-heidelberg.de

Revised 16 September 2002; accepted 19 September 2002 tumour suppressor negatively controls the phosphoinositide-3kinase signalling pathway for regulation of cell proliferation and cell survival (Bonneau and Longy, 2000). Deletions and mutations of PTEN/MMAC1 have been reported in a wide variety of human cancers, including tumours of the brain, the lung, the prostate and the breast (Teng et al, 1997; Bonneau and Longy, 2000; di Cristofano and Pandolfino, 2000), placing this gene among the most commonly mutated genes in human cancer. In melanoma cell lines, inactivating deletions or mutations of PTEN have been reported in 29-43\% (Guldberg et al, 1997; Tsao et al, 1998, 2000). We therefore looked for PTEN/MMAC1 alterations in melanoma resection specimens at mRNA and protein level by semiquantitative RT - PCR, sequencing of cDNA transcripts and immunohistochemistry.

\section{MATERIALS AND METHODS}

\section{Purification of mRNA from melanoma and nevus resection specimens}

Tissue specimens of primary and metastatic melanomas and acquired melanocytic nevi were frozen in liquid nitrogen immediately after resection. Tissues were microdissected to separate tumour from normal tissues. From patients where the PTEN/ $M M A C 1 \mathrm{cDNAs}$ were found to be altered in the melanomas, blood mononuclear cells were purified by Lymphoprep (Nycomed Pharma, Oslo, Norway) and investigated as non-neoplastic tissues. Total RNA was isolated by anion exchange on resin columns (RNA mini kit, QIAGEN, Valencia, CA, USA), concentrated and desalted by isopropanol precipitation and dissolved in $30 \mu \mathrm{l}$ TE $(10 \mathrm{mM}$ Tris $\mathrm{HCl} \mathrm{pH} 8.0,1 \mathrm{~mm}$ EDTA). Contaminating DNA was digested by DNAse (Promega, Madison, WI, USA), and high yields of fulllength, double-stranded cDNA were then synthesised using 'switch- 
ing mechanism at $5^{\prime}$ end of RNA template' (SMART, Clontech, Palo Alto, CA, USA) as previously described (Endege et al, 1999). Briefly, cDNA first strands were synthesized in $10 \mathrm{l}$ solution containing $3 \mu \mathrm{l}$ RNA sample, $1 \mu \mathrm{M}$ cDNA synthesis primer, $1 \mu \mathrm{M}$ SMART II oligonucleotide and $2 \mu \mathrm{l} 5 \times$ first strand buffer (Clontech), 200 units MMLV reverse transcriptase (Gibco, Gaithersburgh, MD, USA), $1 \mu \mathrm{l}$ dNTP mix ( $2 \mathrm{~mm}$ final concentration each) and $2 \mathrm{mM}$ DDT at $42^{\circ} \mathrm{C}$ for $1 \mathrm{~h}$. Multiple second cDNA strands were then synthesized in $100 \mu \mathrm{l}$ volume containing $10 \mu \mathrm{l}$ first strand cDNA, $2 \mu \mathrm{M}$ PCR primer, $2 \mu \mathrm{l}$ Advantage cDNA polmyerase mix and $10 \mu \mathrm{l} 10 \times \mathrm{PCR}$ buffer (Clontech) and $1 \mu \mathrm{l}$ dNTP mix (2 mM final concentration each). Cycle conditions were: $95^{\circ} \mathrm{C} 1 \mathrm{~min}$, followed by multiple cycles at $95^{\circ} \mathrm{C} 5 \mathrm{~s}, 65^{\circ} \mathrm{C} 5 \mathrm{~s}$, $68^{\circ} \mathrm{C} 6 \mathrm{~min}$. After 15, 18, 21 and 24 cycles, $5 \mu \mathrm{l}$ aliquots of each PCR tube were electrophoresed on a $1.2 \%$ agarose/ethidiumbromid gel to determine the optimal number of PCR cycles with high cDNA yields but not high-molecular-weight smear. Presence of cDNA was then checked by PCR amplification of $\beta$-actin in a final volume of $50 \mu \mathrm{l}$ containing 2.5 units Taq DNA polymerase and $5 \mu \mathrm{l} 10 \times$ PCR buffer (Gibco), $0.5 \mu \mathrm{l}$ of each primer $\left(100 \mathrm{pmol} \mu \mathrm{l}^{-1}\right)$ and $3 \mu \mathrm{l} \mathrm{MgCl}_{2} 1.5 \mathrm{~mm}$. PCR conditions were: $95^{\circ} \mathrm{C} 10 \mathrm{~min}, 30$ cycles of $95^{\circ} \mathrm{C} 30 \mathrm{~s}, 55^{\circ} \mathrm{C} 30 \mathrm{~s}, 72^{\circ} \mathrm{C} 30 \mathrm{~s}$, followed by $72^{\circ} \mathrm{C} 10 \mathrm{~min}$. Primer sequences were: SMART II oligonucleotide 5'-AAg CAg Tgg TAA CAA CGC AgA gTA CgC ggg-3'; cDNA synthesis primer $5^{\prime}$-AAg CAg Tgg TAA CAA CgC AgA gTA CT-3'; PCR primer $5^{\prime}$-AAg CAg Tgg TAA CAA CgC AgA gT-3'; $\beta$ actin-509-for 5'-TgA Cgg ggT CAC CCA CAC TgT gCC CAT CTA-3'; $\beta$-actin-1169-rev 5'-CTA gAA gCA TTT gCg gTg gAC gAT ggA ggg- $3^{\prime}$ (human $\beta$-actin gene, accession number emhum 4:HSAC07 X00351, Ponte et al, 1984). All PCR and hybridization steps were performed on a GeneAmp 2400 thermal cycler (Perkin Elmer, Norwalk, CT, USA).

\section{Semi-quantitative reverse transcription (RT) - PCR}

To compare the expression of the PTEN/MMAC1 gene in melanomas with those in acquired melanocytic nevi, we performed semiquantitative RT-PCRs. PTEN/MMAC1 cDNAs were amplified using the primers PTEN-1545-for and PTEN-2277-rev in a first and the primers PTEN-1731-for and PTEN-2277-rev in a seminested PCR. One hundred ng of each cDNA sample were amplified in $50 \mu \mathrm{l}$ PCRs as described above using the conditions $94^{\circ} \mathrm{C} 1 \mathrm{~min}$ and 18 cycles of $94^{\circ} \mathrm{C} 30 \mathrm{~s}, 60^{\circ} \mathrm{C} 30 \mathrm{~s}, 72^{\circ} \mathrm{C} 60 \mathrm{~s}$ in a first, and $12-$ 24 cycles in the semi-nested reaction, followed by $72^{\circ} \mathrm{C} 10 \mathrm{~min}$. Five $\mu \mathrm{l}$ aliquots of each reaction after 30 cycles were electrophoresed on $2 \%$ agarose/ethidiumbromide gels. The number of PCR cycles to detect PTEN/MMAC1 cDNAs in melanomas was compared with those in acquired melanocytic nevi. To ensure the presence of comparable amounts of amplifyable cDNA in the PCRs, a 661 base pairs $\beta$-actin fragment was amplified as housekeeping gene in separate reactions. PCR conditions for $\beta$-actin amplification were: $95^{\circ} \mathrm{C} 1 \mathrm{~min}, 26$ cycles of $95^{\circ} \mathrm{C} 30 \mathrm{~s}, 55^{\circ} \mathrm{C}$ $30 \mathrm{~s}, 72^{\circ} \mathrm{C} 30 \mathrm{~s}$, followed by $72^{\circ} \mathrm{C} 10 \mathrm{~min}$. Primer sequences were: PTEN-1545-for 5'-Agg gAg TAA CTA TTC CCA gTC-3'; PTEN1731-for 5'-CgA Cgg gAA gAC Aag TTC AT-3', PTEN-2277-rev 5'-Tgg TgT TTT ATC CCT CTT gA-3' (PTEN cDNA sequence, accession number U92436; Steck et al, 1997). Results of the semi-quantitative RT-PCRs were statistically analysed by the logrank test for time-to-event data (Mantel-Haenszel test, Mantel and Haenszel, 1959) defining the resulting two-sided $P$-values to be statistically significant for $P<0.05$.

\section{Amplification and sequencing of PTEN/MMAC1 cDNAs}

To screen for mutations and deletions in the coding region of the PTEN/MMAC1 gene, we used unique primers and direct sequencing of the PCR product as previously described (Liu and Kagan, 1999). A 1475 bp DNA fragment was first amplified by PCR using the primers PP1u and PP1d (Wang et al, 2000). In nested PCRs, 602 and 752 bp cDNA fragments were synthesised using the primer pairs F1/R1 and F2/R2, respectively. Cycle conditions were: $94^{\circ} \mathrm{C} 1 \mathrm{~min}, 40$ cycles of $94^{\circ} \mathrm{C} 90 \mathrm{~s}, 56^{\circ} \mathrm{C}$ $120 \mathrm{~s}, 72^{\circ} \mathrm{C} 150 \mathrm{~s}$, followed by $72^{\circ} \mathrm{C} 10 \mathrm{~min}$ in the first PCR and $94^{\circ} \mathrm{C} 1 \mathrm{~min}, 40$ cycles of $94^{\circ} \mathrm{C} 60 \mathrm{~s}, 50^{\circ} \mathrm{C} 120 \mathrm{~s}, 72^{\circ} \mathrm{C}$ $150 \mathrm{~s}$, followed by $72^{\circ} \mathrm{C} 10 \mathrm{~min}$ in the nested PCRs. In each case, as a control for a successful RT of the RNA, we amplified a $661 \mathrm{bp} \beta$-actin cDNA fragment. Primer sequences were: PP1u 5'-AgA gCC ATT TCC ATC CCT gCA-3' (nucleotides 945964); PP1d 5'-gTg TCA AAA CCC TgT ggA Tg-3' (nucleotides 2420-2401; Wang et al, 2000); F1-for 5'-AgC TTC TgC CAT CTC TCT CCT CC-3', R1-rev 5'-gAT TCT TTA ACA ggT AgC TA-3', F2-for 5'-Agg gAg TAA CTA TTC CCA gTC-3' (identical with PTEN-1525-for), R2-rev 5'-Tgg TgT TTT ATC CCT CTT gA-3' (Liu and Kagan, 1999). The DNA bands were visualized on 2\% agarose/ethidiumbromide gels. PTEN/MMAC1 amplificons were then purified and the QIAquick PCR purification kit according to the manufacturer's instructions (QIAGEN) and sequenced at a concentration of $50 \mathrm{ng} \mu \mathrm{l}^{-1}$ with a GeneAmp PCR system 9600 using ABI Prism dGTP BigDye Terminator Ready Reaction Kits and the AmpliTaq DNA polymerase FS according to the manufacturer's protocol (Perkin Elmer, Seqlab, Göttingen, Germany). For sequencing PTEN/MMAC1 cDNA transcripts from both sides, the primers F-1, R-1, F-2 and R-2 were used. PCRs consisted of 25 cycles including a denaturation step at $96^{\circ} \mathrm{C}$ for $10 \mathrm{~s}$, a primer annealing step at $50^{\circ} \mathrm{C}$ for $5 \mathrm{~s}$ and a chain elongation step at $60^{\circ} \mathrm{C}$ for $60 \mathrm{~s}$. Cycle sequencing products were then ethanol precipitated, run on a $4 \%$ polyacrylamide $7 \mathrm{M}$ urea gel and analysed with the ABI Prism 377 Genetic Analyzer (Perkin-Elmer; Seqlab). The resulting sequences were aligned to known DNA sequences in the database of the National Center for Biotechnology Information (NCBI, Bethesda, MD, USA, http://www.ncbi.nlm.nih.gov/BLAST). PTEN/MMAC1 protein sequences predicted by the cDNA sequences were compared with the PTEN/MMAC1 wild type protein sequence using the BLASTX sofware at the NCBI.

\section{Immunohistochemical staining of PTEN/MMAC1 protein}

Serial $4 \mathrm{~m}$-thin paraffin sections from formalin-fixed and paraffinembedded melanoma and acquired melanocytic nevus tissues were deparaffinised and rehydrated in graded ethanol solutions. After retrieval pretreatment by $750 \mathrm{~W}$ microwave at $85^{\circ} \mathrm{C}$ in $0.1 \mathrm{M}$ sodium citrate buffer $\mathrm{pH} 6.0$ for $20 \mathrm{~min}$, unspecific binding was blocked by $10 \%$ goat serum (Vector, Wertheim-Bettingen, Germany). Following overnight incubation at room temperature with the primary antibodies, the sections were washed repeatedly in destilled water and phosphate-buffered saline (PBS). Next, slides were incubated with sheep-anti-mouse-antibody as secondary antibody (Amersham-Buchler, Braunschweig, Germany) and developed using the streptavidin-biotin-peroxidase complex technique as described (Hsu et al, 1981). The visualisation was performed with a nickel-enhanced diaminobenzidine (DAB) reaction, resulting in a black staining of structures containing the epitope (Hsu and Soban, 1982). Sections were counterstained with hematoxylin and mounted with Eukitt ${ }^{\mathbb{R}}$ (Merck, Darmstadt, Germany). The monoclonal antibodies NCL-PTEN (Novocastra, Newcastle upon Tyne, UK, dilution 1:100), S100 (Linaris, Wertheim, Germany, dilution 1:3), HMB45 (Loxo, Dossenheim, Germany, prediluted) and CD68 (Dako, Hamburg, Germany, dilution $1: 80$ ) were used for the detection of the respective proteins. As a negative control, the primary antibody was substituted by equal amounts of normal mouse immunoglobulin G (Santa Cruz Biotechnology, Santa Cruz, CA, USA, dilution 1:100) in parallel experiments. 


\section{RESULTS}

PTEN/MMAC1 gene expression is not down-regulated in melanomas in comparison to acquired melanocytic nevi

Semi-quantitative RT-PCRs were done with 19 acquired melanocytic nevus and 18 melanoma tissue specimens (seven nodular melanomas, 10 superficial spreading melanomas and 1 acrolentiginous melanoma from the tumours listed in Table 1). The presence of comparable amounts of amplifyable cDNA was ensured by amplification of $\beta$-actin as housekeeping gene. Using $100 \mathrm{ng}$ of each sample for 24 PCR cycles, $661 \mathrm{bp} \beta$-actin amplicons of comparable amounts were observed on agarose gels (data not shown). The possibility of amplification of genomic DNA was eliminated by $\beta$-actin PCRs without RT, which were negative in all specimens (data not shown). Next, expression of the PTEN/ MMAC1 gene was evaluated by semi-quantitative PCR analysis. Following 12 cycles of semi-nested PCR, a single acquired melanocytic nevus $(5 \%)$ and a single melanoma $(6 \%)$ were positive. After 14 cycles, five nevi (26\%) and seven melanomas (39\%) showed positive result. The $344 \mathrm{bp}$ amplificons were seen in seven nevi (37\%) and eight melanomas (44\%) following 16 cycles, in 13 nevi $(68 \%)$ and 14 melanomas $(78 \%)$ following 18 cycles, in 15 nevi (79\%) and 17 melanomas (94\%) following 20 and 22 cycles. Following 24 PCR cycles, four nevi and none of the melanomas remained negative. Applying the logrank test for time-to-event data (Mantel-Haenszel test), the resulting two-sided $P$-value of 0.17 indicated no statistically significant difference of the semi-quantitative RT-PCR testing nevi and melanoma tissue samples. We have to remark that due to the relative low number of tested tissue samples the log rank test has limited power to detect differences. The estimated hazard ratio for melanomas versus nevi was 1.6 (95\% confidence interval $0.81 ; 3.23$ ).

\section{Mutations and deletions of PTEN/MMAC1 cDNAs were found in some melanomas}

Twenty-six melanoma resection specimens (seven nodular melanomas, 10 superficial spreading melanomas, one acrolentiginous melanoma, one polypoid melanoma, one melanoma not classified, three cutaneous, three subcutaneous metastases, tumours listed in Table 1) were succesfully used for RNA purification and reverse transcription. Following PCR amplification and sequencing of PTEN/MMAC1 cDNAs, sequences were compared with the known PTEN/MMAC1 cDNA sequence (genbank accession number emhum7:HSU93051; Steck et al, 1997) using the BLASTN software. Three point mutations and two deletions were detected in five melanomas whereas wild type of nucleotide sequence was found in 21 samples (Table 1, Figure 1)

Next, the PTEN/MMAC1 protein sequences predicted by the cDNA sequences that we found were compared with the known PTEN/MMAC1 protein sequence (PTEN_HUMAN 000633 and NM 000314, Li et al, 1997) using the BLASTX sofware. None of the three detected point mutations resulted in changes of amino

Table I Synopsis of the results of PTEN/MMACI cDNA sequences, predicted protein sequences and immunohistochemical staining of melanomas

\begin{tabular}{|c|c|c|c|c|c|c|c|c|c|}
\hline $\begin{array}{l}\text { Type of } \\
\text { melanoma }\end{array}$ & $\begin{array}{c}\text { Breslow } \\
(\mathbf{m m})\end{array}$ & $\begin{array}{l}\text { Clark's } \\
\text { level }\end{array}$ & Localisation & $\begin{array}{c}\text { Age } \\
\text { (years) }\end{array}$ & $\begin{array}{c}\text { Gender } \\
(\mathrm{m} . \mathrm{w})\end{array}$ & $\begin{array}{l}\text { CDNA } \\
\text { sequence }\end{array}$ & $\begin{array}{c}\text { Predicted } \\
\text { protein }\end{array}$ & $\begin{array}{l}\text { Staining of } \\
\text { protein }^{\mathbf{a}}\end{array}$ & Clinical outcome \\
\hline SSM & 0.6 & IV & leg & 62 & $M$ & wt & WT & ++ & NED after $19 \mathrm{~m}$ \\
\hline SSM & 0.6 & III & head & 82 & M & wt & WT & ++ & NED after $22 \mathrm{~m}$ \\
\hline SSM & 1.4 & IV & leg & 54 & $\mathrm{~F}$ & wt & WT & $+/++$ & NED after $55 \mathrm{~m}$ \\
\hline SSM & 1.0 & IV & back & 71 & M & wt & WT & NS & NED after $29 \mathrm{~m}$ \\
\hline SSM & 5.5 & V & foot & 75 & $\mathrm{~F}$ & 2233 del $T$ & N 40I & ++ & LN met after $11 \mathrm{~m}$ \\
\hline SSM & 8.5 & IV & arm & 86 & $\mathrm{~F}$ & wt & WT & $+/++$ & NED after $4 \mathrm{~m}$ \\
\hline SSM & 0.7 & IV & back & 59 & M & wt & WT & ++ & no follow up \\
\hline NM & 1.3 & IV & head & 50 & M & wt & WT & ++ & no follow up \\
\hline NM & 13 & $\mathrm{~V}$ & back & 80 & M & wt & WT & ++ & LN met after I m \\
\hline NM & 3.4 & III & $\operatorname{leg}$ & 27 & M & wt & WT & ++ & NED after 15 m \\
\hline NM & 5.2 & $\mathrm{~V}$ & back & 73 & M & wt & WT & NS & NED after $10 \mathrm{~m}$ \\
\hline NM & 0.3 & III & back & 44 & M & $1420 \mathrm{~g} \rightarrow \mathrm{A}$ & WT & ++ & NED after $27 \mathrm{~m}$ \\
\hline cut. met. $^{c}$ & & & leg & 75 & $\mathrm{~F}$ & wt & WT & $+/++$ & NED after $23 \mathrm{~m}$ \\
\hline cut. met. ${ }^{b}$ & & & head & 79 & $M$ & wt & WT & NS & no follow up \\
\hline cut. met. ${ }^{d}$ & & & leg & 66 & M & $1547 \mathrm{C} \rightarrow \mathrm{T}$ & WT & ++ & no follow up \\
\hline s.c. met. ${ }^{\mathrm{e}}$ & & & arm & 38 & $M$ & wt & WT & ++ & bone met. ${ }^{h}$ \\
\hline s.c. met. $^{f}$ & & & leg & 64 & $\mathrm{~F}$ & wt & WT & $+/++$ & cut. met. after $13 \mathrm{~m}$ \\
\hline s.c . met. ${ }^{g}$ & & & leg & 67 & $\mathrm{~F}$ & wt & WT & $+/++$ & cut. met. after $13 \mathrm{~m}$ \\
\hline
\end{tabular}

$\mathrm{A}=$ adenine; Breslow=tumour thickness according to Breslow; $C=$ cytosine; cut. met.=cutaneous metastasation; del=deletion; $F=f$ female; $g=$ guanine; $L \mathrm{~N}=$ lymph node; $\mathrm{m}=$ months; $M=$ male; $M M=$ melanoma not classified; $N E D=$ no evidence of disease; NM=nodular melanoma; $N$ 393=nonsense protein sequence beginning at amino acid 393; NS=no successful immunohistochemical staining in repeated experiments: $\mathrm{PM}=$ polypoid melanoma; s.c.met.=subcutaneous metastasation; simultan.=simultaneous; SSM=superficial spreading melanoma; T=thymine; wt=wild type of PTEN/MMACI cDNA sequence (according to NCBI accession number U92436); WT=wild type of PTEN/MMACI protein sequence (in comparison to $\mathrm{NCBI}$ accession number $\mathrm{O08586}$ ); $1420 \mathrm{~g} \rightarrow \mathrm{A}=$ exchange of guanine by adenine at nucleotide | 420 . ${ }^{\mathrm{a}} \mathrm{Upon}$ immunohistochemistry, staining of endothelial cells was considered as internal positive control and rated as.$++{ }^{b}$ ALM and cutaneous metastases were diagnosed simultaneously. ${ }^{\mathrm{C}}$ Primary melanoma occurred 19 years before, histology of primary tumour is unknown. ${ }^{\mathrm{d}}$ The primary melanoma at the foot was not further classified, tumour thickness according to Breslow 2.7 mm, Clark's level IV. 'Primary melanoma is unknown. 'Primary melanoma at the leg occurred 53 months ago, tumour thickness according to Breslow 4.3 mm, Clark's level $V$. ' Lentigo maligna melanoma at the leg occurred 24 years ago, tumour thickness according to Breslow not known, Clark's level III. 'Bone metastases developed 2 months before excision of the subcutaneous metastasis. 


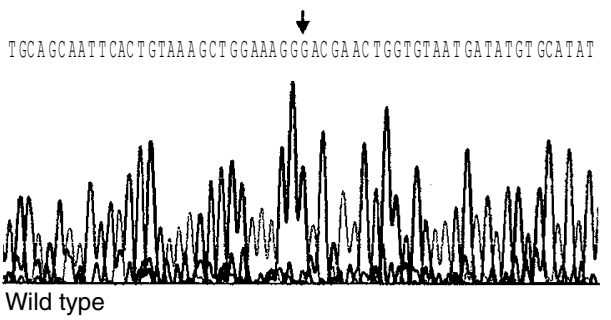

$\downarrow$

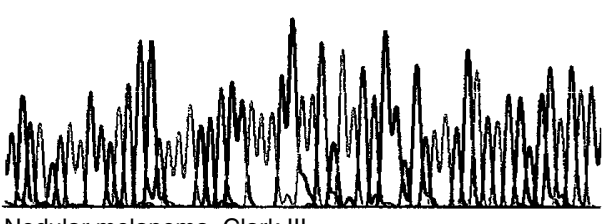

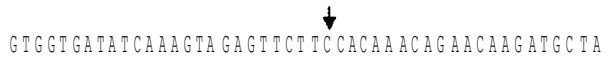

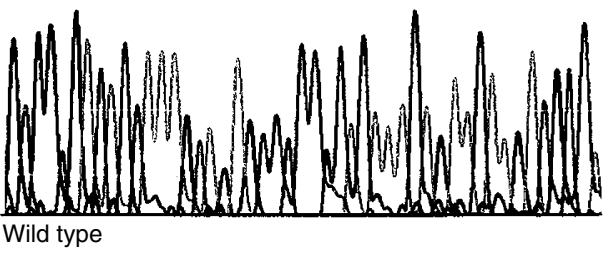

GTGGTGATATCAAAGAGAGTTCTTCACAACACARCAAGATGCTA

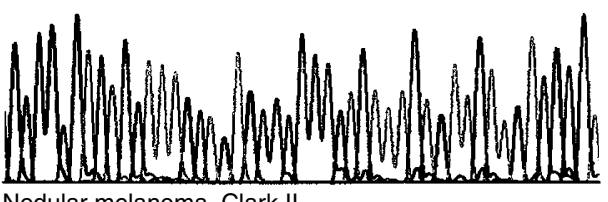

Nodular melanoma, Clark II

Figure I Part of the PTEN/MMACI cDNA sequences in melanomas in comparison to the wild type sequences. Guanine was found to be exchanged by adenine at nucleotide 1420 in a nodular melanoma, Clark's level III (left). Cytosine was found to be exchanged by thymine at nucleotide I808 in a nodular melanoma Clark's level II (right).

A

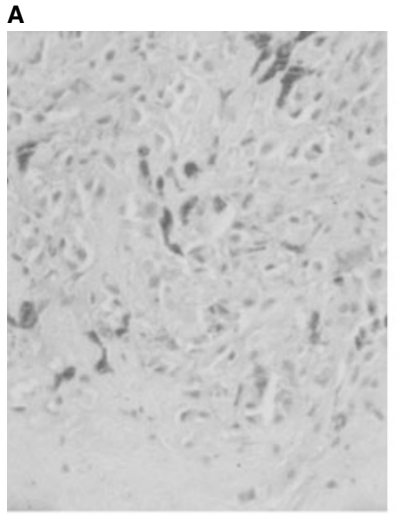

B

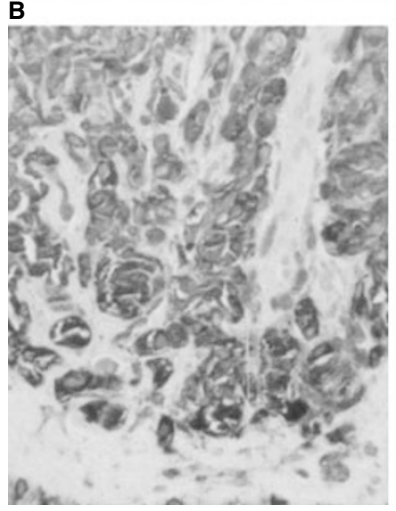

C

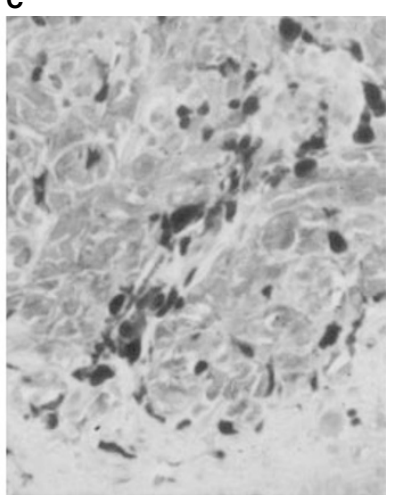

D

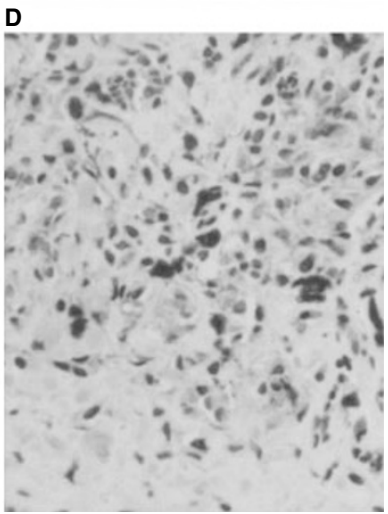

Figure 2 Immunhistochemical staining of serial tissue sections of a nodular melanoma, tumour thickness according to Breslow $1.4 \mathrm{~mm}$, Clark's level IV. The PTEN/MMACI protein was detected in melanoma cells and was not restricted to tumour associated macrophages. (a) Hematoxylin Eosin, (b) HMB45, (c) CD68, (d) PTEN/MMACI staining (all magnification $25 \times$, nickel enhanced $D A B$ reaction resulting in black signals).

acids or stop codons. All three point mutations were silent mutations as they did not alter the predicted protein sequence. The two

deletions that we found resulted in frame shifts of the nucleotide sequence followed by subsequent nonsense protein sequence at the C-terminus of the PTEN/MMAC1 protein without protein truncation. As a consequence, the corresponding PTEN/MMAC1 proteins are predicted to have lost the normal five C-terminal amino acids, which are supposed to function as PDZ-binding consensus sequence (Leslie et al, 2000). Further critical motifs of the PTEN/MMAC1 protein, e.g. the catalytic domain (tyrosin phosphatase domain, Steck et al (1997); Ali et al (1999); genbank accession number O08586, PTEN/MMAC1 exon 5, amino acids 122-132) or the phosphate acceptor sites (residues 233-240, $308-315)$ were altered in none of the 26 predicted PTEN/MMAC1 proteins.

The presence of genetic polymorphisms was excluded by sequencing the PTEN/MMAC1 cDNAs from corresponding blood mononuclear cells, which were regarded as non-neoplastic tissues of the patients where PTEN/MMAC1 cDNAs were found to be altered in the melanoma.

In the clinical follow up, 19 of the 26 patients were seen in regular intervals. Progression of the disease was observed in seven patients with three cutaneous, three lymph node and one bone metastases (Table 1). Looking at the five patients with cDNA alterations, one patient with a deletion in the PTEN/ MMAC1 cDNA suffered from lymph node metastasis 11 months after primary surgery. In respect to statistical correlation of PTEN/MMAC1 cDNA alterations with the clinical course of the disease, the number of investigated melanoma samples was too small.

\section{Immunohistochemical detection of the PTEN protein in melanomas and acquired melanocytic nevi}

Expression of the PTEN/MMAC1 protein was analysed in six acquired melanocytic nevi, 18 primary and five metastatic melanomas. Melanoma tissues corresponded to the samples investigated for PTEN/MMAC1 gene expression and cDNA sequence. Evaluating the tissue sections of the nevi, distinct nuclear staining was seen in the majority of melanocytes which was comparable to the signals in endothelial cells with respect to intensity (data not shown). Immunoreactions were also positive in cells of the hair 
follicles and in part of the cells in the stratum basale of the epidermis.

Nineteen of the 23 melanoma sections had accompanying vascular endothelial cells present, which showed strong PTEN/MMAC1 immunostaining in the nuclei, were graded ++ , and served as internal positive control as described previously (Zhou et al, 2000). In these 19 melanomas, the PTEN/MMAC1 protein was detected in the melanoma cells and was not restricted to tumour associated macrophages (Table 1, Figure 2). In most cases, the intensity of signals in the melanoma cells was comparable to that in endothelial cells and signals were located in the nuclei. In 10 melanomas, nuclear staining intensity varied from weak $(+)$ to moderate $(++)$ nuclear PTEN/MMAC1 immunostaining. In the remaining four of the 23 investigated melanoma tissues, immunohistochemical staining was not successful as endothelial cells remained negative as well.

PTEN/MMAC1 immunohistochemistry was also positive for those two primary melanomas which harboured a nucleotide deletion in the PTEN/MMAC1 cDNA sequence. As these deletions at cDNA level resulted in predicted nonsense sequences of the protein at the C-terminus, the PTEN/MMAC1 protein might further be detected by the monoclonal NCL-PTEN antibody which has been produced by immunisation with the 200 amino acids at the $\mathrm{C}$ terminus.

\section{DISCUSSION}

PTEN/MMAC1 is one of the most commonly mutated genes in human cancer (Teng et al, 1997; Bonneau and Longy, 2000; di Cristofano and Pandolfino, 2000). As this tumour suppressor gene is located at chromosome $10 \mathrm{q} 23.3$ and melanomas frequently harbour deletions at chromosome 10q22-qter (Isshiki et al, 1993; Herbst et al, 1994; Walker et al, 1995; Healy et al, 1996, 1998) like carcinomas of the prostate (Trybus et al, 1996) and the kidney (Speicher et al, 1994), inactivation of PTEN/MMAC1 has been supposed to occur in melanomas. Actually, deletions and mutations of PTEN/MMAC1 have been found in $29-43 \%$ of investigated melanoma cell lines (Guldberg et al, 1997; Tsao et al, 1998; 2000). We therefore tested melanoma primary resection specimens for mRNA and protein expression and PTEN/MMAC1 cDNAs for the presence of mutations or deletions.

Applying semi-quantitative RT - PCR, we could not find a statistically significant down-regulation of the PTEN/MMAC1 expression in melanomas at mRNA level in comparison to acquired melanocytic nevi, from which melanomas are known to arise. Likewise, PTEN/MMAC1 expression was not lost at protein level as we observed distinct nuclear signals in melanoma cells by immunohistochemistry. Our immunohistochemical data contrast to the report of Zhou et al (2000) who described absent or weak expression of PTEN/MMAC1 nuclear signals in four primary and 30 metastatic melanomas and assumed epigenetic PTEN/MMAC1 silencing. Applying the same immunohistochemical protocols, the use of different primary antibodies may cause these divergent results. We used the monoclonal antibody NCL-PTEN which is commercially available while Zhou et al (2000) and coworkers developed their own PTEN/MMAC1-specific antibody 6H2.1.

Alterations of the PTEN/MMAC1 cDNA sequence were detected in five of 26 investigated melanoma resection specimens, among them three silent point mutations. The two deletions that we identified are predicted to result in nonsense protein sequences at the extreme C-terminus of the PTEN/MMAC1 protein. Considering the last three amino acids as consensus sequence for binding PDZ domain containing proteins (Leslie et al, 2000), localisation and function of PTEN/MMAC1 are possibly altered in the corresponding two melanoma primary tumours. As PDZ domains are known to recruit components of lipid signalling pathways to particular membranes (Montell, 1998; Nemoto and de Camilli, 1999), deletion of the PDZ domain may disrupt targeting of the PTENMMAC1 protein to the plasma membrane (Leslie et al, 2000). Refering to the function of PTEN/MMAC1 missing the putative PDZ-targeting sequence, a PTEN/MMAC1 enzyme with a deletion of the C-terminal five amino acids (Q399STOP mutation) has been reported to retain full phosphatase activity but to be impaired in inhibiting cell spreading and platelet derived growth factor (PDGF)-induced membrane ruffling (Leslie et al, 2000; 2001) as well as in inhibiting colony formation (Morimoto et al, 1999). Similar to our findings, C-terminal frame shifts and missense mutations of PTEN/MMAC1 have previously been identified in glioblastomas (Ali et al, 1999; Bonneau and Longy, 2000).

The frequency of somatic mutations and deletions of PTEN/ MMAC1 in melanoma resection specimens is controversially discussed so far: Microsatellite analyses demonstrated $\mathrm{LOH}$ at the PTEN/MMAC1 locus in none of 23 primary cutaneous and 17 metastatic melanomas ( $0 \%$; Böni et al, 1998), in a single of 10 investigated melanomas (10\%; Steck et al, 1997), in two of 44 informative primary and metastatic melanomas (4\%; Herbst et $a l, 1999)$ and in three of eight primary and in 18 of 31 metastatic melanomas (3 and 58\%, respectively; Birck et al, 2000). Applying denaturing gel electrophoresis, none of three primary melanomas with $\mathrm{LOH}$ but four of 61 melanoma metastases harboured mutations of the PTEN/MMAC1 gene (Birck et al, 2000).

Reifenberger et al (2000) reported PTEN/MMAC1 mutations in four of 37 investigated metastases (11\%) from which two had lost one PTEN/MMAC1 allele. Melanoma metastases seem to be affected by $\mathrm{LOH}$ at the PTEN/MMAC1 locus more frequently as was further reported for $33 \%$ of 21 cases; $19 \%$ of these specimens harboured mutations in the remaining allele (Celebi et al, 2000). In addition, Poetsch et al (2001) detected nine intronic mutations in 25 primary and 25 metastatic melanoma resection specimens among them two mutations in metastases resulted in amino acid changes. If these genetic alterations are the cause or the result of metastazation, remains unclear. Mutations of PTEN/MMAC1 in cell lines may be acquired during cell culture at least in some cases as was demonstrated for six melanoma cell lines where none of the mutations found in the cell lines have been recovered in the melanoma resection specimens from which the cell lines had been derived from (Guldberg et al, 1997).

Altogether, involvement of the PTEN/MMAC1 tumour suppressor gene in melanomas remains controversial. Our data do not reveal a statistically significant down-regulation of the PTEN/ MMAC1 expression at mRNA or protein level. Among 26 melanoma resection specimens, we here describe three silent point mutations and two frame shifts of the PTEN/MMAC1 cDNA sequence. The $\mathrm{N}$-terminal phosphatase domain or the phosphate acceptor sites were not affected by any mutation or deletion. The two frame shifts at the extreme C-terminus were harboured by melanoma primary tumours and resulted in a predicted loss of the putative PDZ-targeting consensus sequence probably important in localisation and function of the PTEN/MMAC1 protein. We here first report on single melanoma primary tumours that exhibit PTEN/MMAC1 proteins predicted to lack the C-terminal PDZbinding motif, possibly impairing localization and function of this tumour suppressor protein.

\section{ACKNOWLEDGEMENTS}

This work was supported by a grant from the Faculty of Medicine at the University of Heidelberg (F.203417). 


\section{REFERENCES}

Albino AP, Vidal MJ, McNutt NS, Shea CR, Prieto VG, Nanus DM, Palmer JM, Hayward NK (1994) Mutation and expression of the $p 53$ gene in human malignant melanomas. Melanoma Res 4: 35-45

Ali IU, Schriml LM, Dean M (1999) Mutational spectra of PTEN/MMAC1 gene, a tumour suppressor with lipid phosphatase activity. J Natl Cancer Inst 91: $1922-1931$

Bastian BC, LeBoit PE, Hamm H, Brocker EB, Pinkel D (1998) Chromosomal gains and losses in primary cutaneous melanomas detected by comparative genomic hybridization. Cancer Res 58: $2170-2175$

Birck A, Ahrenkiel V, Zeuthen J, Hou-Jensen K, Guldberg P (2000) Mutation and allelic loss of the PTEN/MMAC1 gene in primary and metastatic melanoma biopsies. J Invest Dermatol 114: $277-280$

Böni R, Vortmeyer AO, Burg G, Hofbauer G, Zhuang Z (1998) The PTEN tumour suppressor gene and malignant melanoma. Melanoma Res 8: $300-302$

Bonneau D, Longy M (2000) Mutations of the human PTEN gene. Hum Mut 16: $109-122$

Celebi JT, Shendrik I, Silvers DN, Peacocke M (2000) Identification of PTEN mutations in metastatic melanoma specimens. J Mol Genet 37: 653-657

Di Cristofano A, Pandolfino PP (2000) The multiple roles of PTEN in tumour suppression. Cell 100: $387-390$

Endege WO, Steinmann KE, Boardman LA, Thibodeau SN, Schlegel R (1999) Representative cDNA libraries and their utility in gene expression profiling. BioTechniques 26: $542-550$

Guldberg P, Straten PT, Brick A, Ahrenkiel V, Kirkin AF, Zeuthen J (1997) Disruption of the MMAC1/PTEN gene by deletion or mutation is a frequent event in malignant melanoma. Cancer Res 57: 3660-3663

Healy E, Belgaid CE, Takata M, Vahlquist A, Rehman I, Rigby H, Rees JL (1996) Allotypes of primary cutaneous melanoma and benign melanocytic nevi. Cancer Res 56: $589-593$

Healy E, Belgaid CE, Takata M, Harrison D, Zhu NW, Burd DA, Rigby HS, Matthews JN, Rees JL (1998) Prognostic significance of allelic losses in primary melanoma. Oncogene 16: 2213-2218

Herbst RA, Weiss J, Ehnis A, Cavenee WK, Arden KC (1994) Loss of heterozygosity for 10q22-10qter in malignant melanoma progression. Cancer Res 54: $3111-3114$

Herbst RA, Podewski EK, Mommert S, Kapp A, Weiss J (1999) PTEN and MXI1 allelic loss on chromosome 10q is rare in melanoma in vivo. Arch Dermatol Res 291: $567-569$

Hsu SM, Raine L, Fanger H (1981) Use of avidin-biotin-peroxidase complex (ABC) in immunoperoxidase techniques. J Histochem Cytochem 29: 577

Hsu SM, Soban E (1982) Color modification of diaminobenzidine (DAB) precipitation by metallic ions and its application for double immunohistochemistry. J Histochem Cytochem 30: 1079

Indsto JO, Holland EA, Kefford RF, Mann GJ (1998) 10 q deletions in metastatic cutaneous melanoma. Cancer Genet Cytogenet 100: 68-71

Isshiki K, Elder DE, Guerry D, Linnenbach AJ (1993) Chromosome 10 allelic loss in malignant melanoma. Genes Chrom Cancer 8: $178-184$

Leslie NR, Gray A, Pass I, Orchiston EA, Downes CP (2000) Analysis of the cellular functions of PTEN using catalytic domain and C-terminal mutations, differential effects of C-terminal deletion on signalling pathways downstream of phosphoinositide 3-kinase. Biochem J 346: 827-833

Leslie NR, Bennett D, Gray A, Pass I, Hoang-Xuan K, Downes CP (2001) Targeting mutants of PTEN reveal distinct subsets of tumour suppressor functions. Biochem J 357: 427-435

Li J, Yen C, Liaw D, Podsypanina K, Bose S, Wang SI, Puc J, Miliaresis C, Rodgers L, McCombie R, Bigner SH, Giovanella BC, Ittmann M, Tycko B, Hibshoosh H, Wigler MH, Parsons R (1997) PTEN, a putative protein tyrosine phosphatase gene mutated in human brain, breast and prostate cancer. Science 275: 1943 - 1947

Liu J, Kagan J (1999) Method to distinguish between the MMAC1/PTEN gene and its pseudogene in RT-PCR analysis of point mutations. BioTechniques 26: $19-24$

Mantel N, Haenszel W (1959) Statistical aspects of the analysis of data from retrospective studies of disease. J Natl Cancer Inst 22: 719-748

Montell C (1998) TRP trapped in fly signaling weg. Curr Opin Neurobiol 8: $389-397$

Morimoto AM, Berson AE, Fujii GH, Teng DH, Tavtigian SV, Bookstein R, Steck PA, Bolen JB (1999) Phenotypic analysis of human glioma cells expressing the MMAC1 tumor suppressor phosphatase. Oncogene 18: $1261-1266$
Nagase S, Sato S, Tezuka F, Wada Y, Yajima A, Horii A (1996) Deletion mapping on chromosome 10q25-q26 in human endometrial cancer. $\mathrm{Br} J$ Cancer 74: $1979-1983$

Nelen MR, Padberg GW, Peeters EA, Lin AY, van den Helm B, Frants RR, Coulon V, Goldstein AM, van Reen MM, Easton DF, Eeles RA, Hodgsen S, Mulvihill JJ, Murday VA, Trucker MA, Marimam EC, Starink TM, Ponder BA, Ropers HH, Kremer H, Longy M, Eng C (1996) Localization of the gene for Cowden disease to chromosome 10q22-23. Nat Genet 13. $114-116$

Nemoto Y, De Camilli P (1999) Recruitment of an alternatively spliced form of synaptojanin 2 to mitochondria by the interaction with the PDZ domain of a mitochondrial outer membrane protein. EMBO J 18: $2991-3006$

Newton JA (1994) Genetics of melanoma. Br Med Bull 50: 677-687

Parmiter AH, Balaban G, Clark Jr WH, Nowell PC (1988) Possible involvement of the chromosome region 10q24-q26 in early stages of melanocytic neoplasia. Cancer Genet Cytogenet 30: 313-317

Poetsch M, Dittberner T, Woenckhaus C (2001) PTEN/MMAC1 in malignant melanoma and its importance for tumor progression. Cancer Genet Cytogenet 125: $21-26$

Ponte P, Ng S, Engel J, Gunning P, Kedes L (1984) Evolutionary conservation in the untranslated regions of actin mRNAs, DNA sequence of a human beta-actin cDNA. Nucleic Acids Res 12: 1687-1696

Raskind WH, Conrad EU, Matsushita M (1996) Frequent loss of heterozygosity for markers on chromosome arm $10 \mathrm{q}$ in chondrosarkomas. Genes Chrom Cancer 16: $138-143$

Reifenberger J, Wolter M, Bostrom J, Buschges R, Schulte KW, Megahed M Ruzicka T, Reifenberger G (2000) Allelic losses on chromosome arm 10q and mutation of the PTEN (MMAC1) tumour suppressor gene in primary and metastatic malignant melanomas. Virchows Arch 436: 487-493

Richmond A, Fine R, Murray D, Lawson DH, Priest JH (1986) Growth factor and cytogenetic abnormalities in cultured nevi and malignant melanomas. J Invest Dermatol 86: 295-302

Rigel DS, Frieman RJ, Kopf AW (1996) The incidence of malignant melanoma in the United States, issues as we approach the 21st century. J Am Acad Dermatol 34: $839-847$

Robertson GP, Herbst RA, Nagane M, Huang HJ, Cavenee WK (1999) The chromosome 10 monosomy common in human melanoma results from loss of two separate tumor suppressor loci. Cancer Res 59: 3596-3601

Speicher MR, Schoell B, du Manoir S, Schröck E, Ried T, Cremer T, Störkel S, Kovacs A, Kovacs G (1994) Specific loss of chromosomes 1, 2, 6, 10, 13, 17, and 21 in chromophobe renal cell carcinomas revealed by comparative genomic hybridization. Am J Pathol 145: 356-364

Steck PA, Pershouse MA, Jasser SA, Yung WK, Lin H, Ligon AH, Langford LA, Baumgard ML, Hattier T, Davis T, Frye C, Hu R, Swedlund B, Teng DH, Tavtigian SV (1997) Identification of a candidate tumor suppressor gene, MMAC1, at chromosome $10 \mathrm{q} 23.3$ that is mutated in multiple advances cancers. Nature Genet 15: 356-362

Teng DHF, Hu R, Lin H, Davis T, Iliev D, Frye C, Swedlund B, Hansen KL (1997) MMAC1/PTEN mutations in primary tumor specimens and tumor cell lines.. Cancer Res 57: 5221-5225

Trybus TM, Burgess AC, Wojno KJ, Glover TW, Macoska JA (1996) Distinct areas of allelic loss on chromosomal regions $10 \mathrm{p}$ and $10 \mathrm{q}$ in human prostate cancer. Cancer Res 56: $2263-2267$

Tsao H, Zhang X, Benoit E, Haluska FG (1998) Identification of PTEN/ $M M A C 1$ alterations in uncultured melanomas and melanoma cell lines. Oncogene 16: 3397 - 3402

Tsao H, Zhang X, Fowlkes K, Haluska FG (2000) Relative reciprocity of NRAS and PTEN/MMAC1 alterations in cutaneous melanoma cell lines. Cancer Res 60: 1800-1804

Walker GJ, Palmer JM, Walters MK, Hayward NK (1995) A genetic model of melanoma tumorigenesis based on allelic loss. Genes Chrom. Cancer 12: $134-141$

Wang NM, Chang JG, Liu TC, Lin SF, Peng CT, Tsai FJ, Tsai CH (2000) Abberant transcripts of FHIT, TSG101 and PTEN/MMAC1 genes in normal peripheral mononuclear cells. Int J Oncol 16: $75-80$

Zhou XP, Grimm O, Hampel H, Niemann T, Walker MJ, Eng C (2000) Epigentic PTEN silencing in malignant melanomas without PTEN mutation. Am J Pathol 157: 1123-1128 